\title{
The Bologna Reform of Teacher Education in Ukraine and Hungary: A Comparative Analysis
}

\author{
Borkach E. \\ Vice-rektor, Ferenc Rákóczi II Transcarpathian Hungarian Institute, Berehove, Ukraine \\ *Corresponding author: barkatsj@gmail.com
}

Received September 30, 2013; Revised October 12, 2013; Accepted November 14, 2013

\begin{abstract}
The present article describes the main features of a two-stage model of teacher training in Hungary and Ukraine during the years 2006-2013. This time was sufficient enough for the basic training of future teachers, and this model continues to work today. In Hungary, the reduction in undergraduate training to 3 years resulted in a decline in the quality of training; the two-stage model also resulted in significant reduction of students at teacher training. This led to criticism of experts and the shift to a new model of teacher training with the scheme $4+1$ and $5+1$, the implementation of which was provided in 2013.
\end{abstract}

Keywords: Bologna reform, teacher education, model of teacher training, comparative analysis of the educational systems, Hungary, Ukraine

Cite This Article: Borkach E., "The Bologna Reform of Teacher Education in Ukraine and Hungary: A Comparative Analysis.” American Journal of Educational Research 1, no. 11 (2013): 528-533. doi: 10.12691/education$1-11-12$.

\section{Introduction}

The entire civilized world is in a relentless search for new ways of organizing democratic educational system that would allow to increase efficiency, reduce expenses, and provide quickly updatable content of training in accordance with the labour market needs of general education. The Bologna transformation of higher education is a task associated with the creation of a single European Higher Education Area - providing real student mobility, credit transfer and mutual recognition of diplomas - it needs coordination of the content and structure of training of the participating countries. In each of them the transition to two-stage model of teacher training caused a lot of discussion and has its own peculiarities. The changes caused by joining the Bologna Process increased the interest in the theoretical and practical experience of the European countries that have already implemented or are only carrying out the reform of its own education system. Ukraine and Hungary are perfect examples for these countries.

The aim of this study was to determine the efficacy and the main consequences of the transformation of teacher education in these countries to ensure its integration into the European Higher Education and compliance with European standards.

\section{Methods of Analysis}

To achieve the objectives, the author carried out thorough analysis of legal and educational documents and the literature on the theory and practice of teacher training in Ukraine and Hungary.

\section{Results and Discussion}

Training of secondary school teachers in these countries has a long tradition and has experienced the largest rise in the second half of the 20th century. Until the end of the last century, the teaching profession had high prestige among the Hungarian people, resulting in the contests during entrance exams in pedagogical universities. With the collapse of the Eastern Bloc, changes have undergone in economic structure and as a result, market conditions began to determine the structure of training and teaching not only in private but also in many public higher education institutions. The political and socio-economic changes that occurred in the region radically changed the system of social values in both countries. As a result, the teaching profession lost its former prestige in both countries. Changing social values, as well as the low prestige of the teaching profession, the decline of production are those factors that have led to a decrease in the number of students in the teaching profession. In such circumstances, teacher training in both countries met the accession to the European higher education reform, known as the Bologna Process. The idea of creating a single European Space of Higher Education increased interest to the progress of reform in other European countries, especially those in which the situation in higher education has developed similarly. Hungary and Ukraine are precisely those countries.

\subsection{The Bologna Model of Teacher Training in Hungary}

The Hungarian education system is in a continuous process of transformation according to the requirements of the time. 
Joining the Bologna process and the transition to a twostep training system radically changed the system of higher education in Hungary. Training in colleges and universities was replaced by a unified bachelor and master training. Due to the approval of unified training program and qualification requirements, starting from 2006-2007 training in all high schools in Hungary goes by one educational program. Specification of high schools and universities now is possible only in the variable part of training.

In the year 2003 the credit-modular system was introduced in the schools of Hungary. One credit requires 30 hours of study, and one semester course consists of 30 credits.

In the year 2006, after careful preparation, the program and the qualification requirements of teacher training were approved, part of which was allocated to the study of psycho-pedagogical disciplines, and methods of teaching primary and secondary professions [1]. One semester was given to teaching practice. In all pedagogical specializations it was implemented that the mastery of teaching competencies started only after the basic higher education. University graduates are eligible to teach at the school only after receiving the master's degree.

\subsection{The Main Features of the Bologna Model of Teacher Training in Hungary}

The main features of the Bologna model of teacher training in Hungary are:

- Teachers qualification can be obtained only after the student obtained the master's degree.

- A single teacher's specialty was introduced. The list of disciplines that graduate has the right to teach at the school is determined by the specific modules of different disciplines he was learning during the master training.

- Entrance exams are required to enter the master training.

- The graduate students have a half year teaching practice after finishing the master training.

The training is done by the scheme of the $3+2$. The term of bachelor training is three years, the master training - two years. The two-stage system was supposed to eliminate not only the differences in the quality of training, but also the stress associated with the higher prestige of teacher training in universities [2]. However, in the design of the new system doubts appeared regarding the successful resolution of the problem [3]. And the complexity of problems of implementation of the real mobility of students and teachers at all levels and in all forms of training were evident for almost everyone [4].

Given the requirements of general education, teacher training in Hungary is carried out in two directions, in spite of the fact that in the Bologna System, students are accepted for training in single direction.

In the Bologna model primary teaching professions may be: philology, mathematics, history, communication, human and society, pedagogy, biology, physics, chemistry, geography, visual culture and the culture of the environment, science, natural science, physical education. There are also teaching professions, which can only be optional, i.e. studied in parallel with the first profession acquired as a second profession. Among them: the preparation for teaching school subjects in a foreign language, preparation for the implementation of special educational tasks of educational institutions, teachers' specialty speech therapist, teacher of philosophy, management. The fusion of teaching areas in Hungary is arbitrary. When students are choosing teachers' specialization, along with their personal inclinations, the main reason for the choice is that at teacher training significant part of subjects consists of general disciplines of primary and secondary directions. Typical examples are the unification of physics and mathematics, biology and chemistry, mathematics and computer science, etc. If the student has not taken the opportunity to choose the second teacher's direction, he can do it after graduating at the first teacher training, by completing two more semesters.

Students, who have chosen the teacher's specialization in the primary directions, can acquire 100 credits. Ten more credits students gain by studying the discipline of their own choice and preparing the qualifying work. Firstyear students who are preparing for the teacher's specialization should, as a secondary specialization, choose the basic module of another teacher's direction, which provides them 50 credits as well as learn psychological and pedagogical disciplines, providing 10 credits. The general point of view was that in this system students will gain enough basic knowledge to continue the studies in masters training on two specializations. To complete the Bachelor's degree students must accumulate at least 180 credits (Table 1).

Table 1. Structure of the basic training of teachers in Hungary and Ukraine (2006-2013)

\begin{tabular}{|c|c|c|}
\hline & Hungary & Ukraine \\
\hline Credit & 30 hours of training & 36 hours of training \\
\hline Duration of training & 3 years & 4 years \\
\hline Credits & 180 & 240 \\
\hline Hours & 5400 & 8640 \\
\hline $\begin{array}{c}\text { Secondary teaching } \\
\text { specialization }\end{array}$ & required & not required \\
\hline $\begin{array}{l}\text { optional subjects } \\
\text { (students choice) }\end{array}$ & 10 credits & $\begin{array}{c}10 \% \text { of each cycle of } \\
\text { training }\end{array}$ \\
\hline $\begin{array}{c}\text { Teaching practice in } \\
\text { the school }\end{array}$ & - & 6 weeks \\
\hline Degree thesis & required & not required \\
\hline $\begin{array}{l}\text { National standard } \\
\text { for the training }\end{array}$ & Present for all areas & Present for all areas \\
\hline Professional rights & - & $\begin{array}{l}\text { Right to teach in a } \\
\text { secondary school }\end{array}$ \\
\hline Academic rights & $\begin{array}{c}\text { Right to enter } \\
\text { master training }\end{array}$ & $\begin{array}{l}\text { Right to enter specialist } \\
\text { and master training }\end{array}$ \\
\hline
\end{tabular}

According to the content of psycho-pedagogical modules the basic teacher training usually includes courses in theoretical foundations of psychology, history, pedagogy, social pedagogy, and introduction to the specialization. The ratio of theoretical and practical training in this unit is 60 to $40 \%$.

During the master training student must earn 150 credits, 30 of them comes from the teacher's practice for one semester at the end of training (Table 2).

The purpose of master training is to prepare future teachers on the basis of the bachelor training. They should be able to perform common tasks associated with teaching activities, pedagogical research, planning and development in the field of general and vocational education, adult education, and continuing education in doctoral programs. One of the most important tasks of master teacher training was the elimination of quantitative 
and qualitative differences in students' knowledge, resulting from asymmetry of training in two specialties during the bachelor training. Therefore students on master training in the primary direction (basic specialty) can acquire 30 credits. They are assigned to the study of teaching methods, classroom practice, the discipline of the free choice of the student and to the training of professional discipline. Thus, the complete training in basic specialty is 130 credits.

During the master training students can acquire 20 credits in secondary specialty. This was allowed for the elimination of differences in training for primary and secondary specialty, which was formed in undergraduate training. Another 30 credits are given for professional master's training, that is, as many as in the main specialty. In total students get 100 credits for secondary specialty during the bachelor and master trainings which is 30 credits less than they get for the basic specialty.

In psycho-pedagogical training at master training students get 40 credits. Along with the 10 credits obtained in the bachelor training, psychological and pedagogical training of future teachers is 50 credits.

Total preparation of future teachers in a two-stage model lasts five and a half years and requires the execution of 330 credits (Table 4). Their distribution is essentially dependent on which specialty was the basic and which specialty was the secondary training. One cycle of this scheme was enough to determine that it does not allow completing the training of future teachers on secondary specialty.

\subsection{The Bologna Model of Teacher Training in Ukraine}

In Ukraine the graduation in masters training can also be achieved in an educational system which consists of two levels based on each other. The BSc full time course takes four years; the long distance education usually is one year longer. The BSc provides only a singly specialty. The first training level provides knowledge and skills which can be effectively applied in the labour market, as it is defined in the legislation it allows you to work in certain positions. At the same time it gives the student a proper theoretical background to continue the training immediately or resume it later in the specialists or master's degree training.

The specialist training lasts for one year, the master's training, lasts one-or two-years. Students can enter specialist, or master training only after obtaining bachelor degree. The difference between the two trainings is that the specialist training prepares the graduates for dealing with practical tasks, while the master's training prepares graduates to manage the tasks of research and higher education of students. If a student graduated on the second level of higher education - regardless of whether he graduated as specialist or master training - he can gain admission to the $\mathrm{PhD}$ (in Ukraine called aspirantura) training where you earn $\mathrm{PhD}$ degree (in Ukraine called Candidate of Science - CSc).

In Ukraine the credit system was introduced a decade ago. The peculiarity of Ukrainian higher education system is that one credit is equivalent to 36 hours of - classroom lessons, consultation, and self-dependent training. The smallest module can contain 18 hours of training (classroom lessons, consultation, and self-dependent training together) which makes 0,5 credits. A few years ago one credit was equivalent to 54 hours of training. In 2009 an attempt was made to reform the system and make one credit equivalent to 30 hours of training, but there was no implementation of this regulation. In the bachelor training the weekly course load cannot exceed 30 lessons, in the specialist training 24 , in the master training 16 . At the teacher training specialties, according with the Ukrainian state standards the weekly course load is 28 classroom lessons. The academic load in Ukrainian higher education can be 54 hours of - classroom lessons, consultation, and self-dependent training in total. This means that students can acquire 1,5 credits in one week. One semester can last 18 weeks. The examination period lasts at least two weeks. To successfully finish a year a student must acquire 60 credits. During the whole bachelor training students have to complete 240 credits (Table 1).

Until 2007 the teacher training in Ukraine went in the traditional way, according to the system inherited from Soviet Union, in the special teacher trainer colleges and universities, by different programs in each establishment. The four-year college education focused on training for the teaching profession. At the universities, the academic, scientific, and research training received greater emphasis. The graduates from both colleges and universities received diplomas of higher education, which allowed them the entrance to the aspirantura. The difference between college and university education are manifested in the certificate: the teachers who graduated from teacher training colleges were qualified as school teachers, the teachers who graduated from university received degrees which provided qualification allowing teaching at higher education establishments. University training has traditionally had and still has higher social prestige.

The 1719th government Regulation [7] of 2006 December $13^{\text {th }}$ reorganized the list of trainings and courses in Ukrainian higher education establishments, dividing them into fields of science and study. One single teacher training does not exist now. In he list of BSc trainings the courses on which students can obtain teacher qualification are marked by *, this means that on these courses the students - in accordance with the teacher training state standards - in addition to standard specialization training have pedagogical, psychological and methodological, theoretical and practical teaching training which is indispensable for acquiring teacher qualification. The graduates can work as schoolteachers, or can continue their studies on specialist SSc, or master MSc training.

With the 2007 December $6^{\text {th }} 1 / 9-736$. Ministerial Decree [8] strict regulations came into effect regarding the secondary specialization, and choice of second profession. The peculiarity of this regulation is that the basic and secondary professions are not always symmetrical. For example, next to the history specialization as second (additional) specialization geography can be chosen, next to the geography, as additional specialization, biology can be chosen but not vice versa. The secondary specialization on BSc training is not obligatory.

The old standards remain in effect, the 2009 July $9^{\text {th }}$ 642 Ministerial decree made changes only in the list of training subjects. The amount of general subjects 
decreased but the amount of pedagogy and psychology subjects increased, just as the number practical lessons. There is still no national standard for specialist and master's teachers training.

\subsection{Comparative Characteristics of the Structure of Teacher Training in Hungary and Ukraine}

Ukrainian community of education has sought to preserve the achievements of Ukrainian national system of teacher training, but at the same time carefully studied the experience of other countries. Hungary has not only joined the Bologna Process, but became a member of the European Union. This fact gives particular importance to the Hungarian experience. The two-stage model of teacher education in Ukraine is similar to the old system of training in colleges and universities. In Ukraine the bachelor training of 4 years with $20 \%$ more time of training for one credit, the number of weeks in a semester, a deliberate choice of basic and secondary specialization during the college entrance, etc. made it possible to preserve the integrity of the teacher training. At the same time, 4 years of bachelor training imply considerable more costs for both students and parents, just as for the budget of the country. However, the status of bachelor in the labour market in Ukraine is still not completely defined.

Peculiarity of the Ukrainian training system is the similarity to training methods found in some Post-Soviet countries. So far there are no state standards for the master and specialist teacher training of all teachers' specialties. Each institution defines the content of training by itself, and then agrees it with the Ministry of Education and Science. Teachers' practice in school is usually 6 weeks. Specialist diploma in Ukraine allows to teach at all levels of secondary education and to continue training in postgraduate school. This creates some difficulties with its recognition abroad, namely in Hungary. If in Hungary, the Ukrainian students with SSc diploma are joining Master training, their diploma is recognized as a Bachelor's Degree, but if the student is joining $\mathrm{PhD}$ program, their diploma is qualified as a Master's Degree. Primarily this causes problems for representatives of the Hungarian minority in Ukraine. The opinions about specialist diploma still show great differences in Hungary, in some opinions the SSc diploma cannot be recognized as a full value certificate proving graduation.

Table 2. The structure of teacher training at the level of specialist Ukraine (2006-2013)

\begin{tabular}{|c|c|}
\hline Duration of training & 1 years \\
\hline Credits & 60 \\
\hline Hours & 2160 \\
\hline Secondary teaching specialization & not required \\
\hline Teaching practice in the school & 6 weeks \\
\hline Degree thesis & not required \\
\hline National standard for the training & present only in some specialties \\
\hline Professional rights & $\begin{array}{c}\text { Right to teach in a secondary and } \\
\text { middle school }\end{array}$ \\
\hline Academic rights & Right to enter master training \\
\hline
\end{tabular}

The main difference between the master training of future teachers in Hungary and Ukraine was the opportunity to complete the master' training in Ukraine in one year (Table 2). The Hungarian peculiarity was the future teacher's school practice at the end of training. In Ukraine, there is no state standard for master's training, so its scope and content are not precisely defined. A master's degree in Ukraine, under certain conditions, allows teaching at the university. Therefore, future masters in Ukraine are having their teaching practice not in schools but in higher education establishments.

Total preparation of future teachers in a two-stage model in Ukraine lasts five years and requires the execution of 300 credits (Table 4).

Table 3. Structure of teacher master training in Ukraine and Hungary (2006-2013)

\begin{tabular}{|c|c|c|}
\hline & Hungary & Ukraine \\
\hline Duration of training & 2,5 years & 1-2 year \\
\hline Credits & 150 & $60-120$ \\
\hline Hours & 4500 & $2160-4320$ \\
\hline $\begin{array}{c}\text { Secondary teaching } \\
\text { specialization }\end{array}$ & required & not required \\
\hline $\begin{array}{l}\text { optional subjects } \\
\text { (students choice) }\end{array}$ & $5 \%$ & $10 \%$ \\
\hline Degree thesis & required & required \\
\hline $\begin{array}{l}\text { Teaching practice } \\
\text { in the school }\end{array}$ & 6 month & not determinated \\
\hline $\begin{array}{l}\text { National standard } \\
\text { for the training }\end{array}$ & $\begin{array}{l}\text { present for all } \\
\text { specialties }\end{array}$ & $\begin{array}{l}\text { present only in some } \\
\text { specialties }\end{array}$ \\
\hline Professional rights & $\begin{array}{l}\text { Right to teach in a } \\
\text { secondary and middle } \\
\text { school }\end{array}$ & $\begin{array}{c}\text { Right to teach in a } \\
\text { secondary and middle } \\
\text { school }\end{array}$ \\
\hline Academic rights & $\begin{array}{l}\text { Right to enter PhD } \\
\text { training }\end{array}$ & $\begin{array}{l}\text { Right to enter master } \\
\text { training, or aspirantura }\end{array}$ \\
\hline
\end{tabular}

Table 4. The total volume of training of the future teachers in Hungary and Ukraine (2006-2013)

\begin{tabular}{|c|c|c|}
\hline & Hungary & Ukraine \\
\hline Duration of training & 5,5 years & 5 year \\
\hline Credits & 330 & 300 \\
\hline Hours & 9900 & 10800 \\
\hline
\end{tabular}

Both the Hungarian and Ukrainian systems of teacher training have had and have their advantages and disadvantages. The comparative characteristic of the structures of teacher training in Hungary and Ukraine does not allow us to give preference to any of them. Despite a long and thorough preparation for the introduction of a new system of teacher training in Hungary, like Bologna transformation of education in general, the reform received negative and serious criticism from Hungarian experts. In the educational community Hungary quickly formed the opinion that even a short term experience of Bologna system is sufficient to state unequivocally that the two-stage model of higher education cannot solve any problem of teacher training. Disadvantages of the new system are most visible in the faculties of natural science. First of all, the dramatic decrease in the number of students in the teaching professions is associated with the introduction of Bologna model, although interest towards the teaching profession began to decline at the end of the last century. If unfavorable tendency continues, then in a few years, at least in the natural faculties of the leading Hungarian universities the teacher training will stop, leading to an acute shortage of professionals in the public education system of the country. One of the causes for this situation is the student's specialization at the end of the first year during which they do not study any educational 
discipline, which could direct the choice towards the teaching profession. At a time when the prestige of the teaching profession is record low, educational specialization is usually chosen by students with low academic performance, if it is chosen at all. The quality teacher training was also effected by differences in the amount of professional training of teachers in various forms of education. However, there was no such problem during the traditional training in two specialties before the Bologna system. Since these problems have arisen as a result of two-stage training system of higher education, the Hungarian experts see the only way to solve the accumulated problems, by returning to the integrated system of teacher training which was used before the Bologna reform [5].

A timely resolution of the problem might help to bring the teaching profession and the teacher training out of deep crisis, and deprive the teaching profession of hopelessness which is so discouraging to the students. Hungary is restoring the single-stage integrated teacher training, while preserves the training of teachers' on two specialties [6].

In two-stage model of training in Hungary only very few teacher graduates received their diplomas. Therefore, by the time when the enrollee of 2013 will be trained in the new integrated single stage system in Hungary a significant shortage of teachers is expected, which, no doubt, will be conducive to employment of young specialists. Simultaneously with the reintroduction of single-stage model of teacher training the Hungarian government introduces a new model of life-path career development of the teacher, which should provide a worthy and satisfactory life to people who have chosen teacher's profession. The new model provides the necessary financial support to students of pedagogical establishments in the form of additional scholarships. Teacher training has always been the task of the state. Therefore there cannot be any question about selffinanced training.

The teacher training schools are designed for 4 years training cycle, which is extended further with the teaching practice in school for one year. In the future training of secondary school teachers will last 5 years and they will have 1 year of teaching practice. The preservation of training in two teachers' specialties means that every student will have to choose two specialities at entry to university. These are well-known specialties of general education teachers. There are no restrictions to their choice; you can select one natural science and one from humanities. Obviously, there are exceptions, musical training for example.

The training of students during the first three years can go both according to the scheme $4+1$ or $5+1$. Only after the first three years the student has to decide in which scheme he will continue his studies. There is also a possibility to do a mixed option.

Table 5. The structure of the new single-stage model of teacher training in Hungary

\begin{tabular}{|c|c|c|c|}
\hline & Secondary school teacher & Middle school teacher & $\begin{array}{c}\text { In one specialty a teacher of secondary } \\
\text { school, in other }- \text { middle school teacher }\end{array}$ \\
\hline Duration of training & $4+1$ years $=5$ years & $5+1$ years $=6$ years & $4,5+1$ years $=5,5$ years \\
\hline Credits & 300 credits & 360 credits & 330 credits \\
\hline Professional training & 200 credits $(100$ credits for each \\
specialty) & 260 credits $(130$ credits for each & 230 credits $(100$ and 130 credits) \\
\hline $\begin{array}{c}\text { Pedagogical training and } \\
\text { irrevocable teachers' practice }\end{array}$ & 50 credits & 50 credits & 50 credits \\
\hline Individual teachers' practice & 1 year, 40 credits & 1 year, 40 credits & 1 year, 40 credits \\
\hline Diploma Thesis & 10 credits & 10 credits & 10 credits \\
\hline
\end{tabular}

\section{Conclusion}

The entire civilized world is in a relentless search for new ways of organizing democratic educational system that would allow it to increase efficiency, reduce expenses, and provide quickly updatable content of training in accordance with the labour market needs of general education. The Bologna transformation of higher education is a task associated with the creation of a single European Higher Education Area - providing real student mobility, credit transfer and mutual recognition of diplomas - it needs coordination of the content and structure of training of the participating countries. In each of them the transition to two-stage model of teacher training caused a lot of discussion and has its own peculiarities. The changes caused by joining the Bologna Process increased the interest in the theoretical and practical experience of the European countries that have already implemented or are only carrying out the reform of its own education system. Ukraine and Hungary are perfect examples for these countries.

According to the results of the entrance examinations of year 2013 the number of students who have chosen teacher training in a $4+1$ and $5+1$, is slightly higher than in the previous year. The educational community in Hungary hopes to maintain this positive tendency.

The stated above facts, paradoxically indicate that the Hungarian model of teacher training becomes similar to Ukrainian, and not vice versa, as expected. Although the Ukrainian teacher training continues to operate with twostage education system, two types of training remain at the second level (specialist and magister). The BSc is still four years long; the training of general subjects is a semester in the number of lessons. The remaining specialist training takes one year, the MSc training can be one or two years long. More and more attention is paid to the teaching of optional subjects. Decisions regarding the reformation of education in Ukraine are often made in haste and so they often cause a lot of trouble for the students and teachers participating in the training. The Ukrainian teacher education reform has not ended yet, its culmination is expected after the acceptance of the new Law on Higher Education.

The first conclusions about which of the two systems can better cope with the problem of teacher training can be made in 4-5 years, after the completion of a full training cycle. 


\section{References}

[1] "Ordinance of Ministry of Education No. 15/2006. (IV. 3.) on "The undergraduate and graduate degree programs for training and outcome requirements"," Hungarian Gazette, 153(I), 1204212102, Dec. 2006.

[2] Mózes, M. "The introduction of the two-level teacher training mission" in The Bologna Declaration and the Hungarian higher education. Hungarian Accreditation Committee, Budapest, 78-82, 2002.

[3] Dinya, L. "The 'Bologna process' in the dual training system perspective II,” Hungarian Higher Education, 8, 22-25, 2002.

[4] Barakonyi, K. "The modernization trap. Bologna declaration of basic ideas, the academic work to do," Hungarian Higher Education, 1-3, 27-30, 2003.

[5] Tasnádi, P. "Past, present and uncertain future - the Physics Teacher Education Eötvös 'n' in Physics Teaching meaningful and interesting. English teachers teaching Physics International
Conference, Budapest, 2009 August 27-29, Graduate School of Physics, Eötvös University, Budapest, 101-106, 2010.

[6] "Ordinance of Ministry of Human Resources No. 8/2013. (I. 30) on "The joint training requirements for teachers and individual teachers training and outcome requirements", Hungarian Gazette. 15, 979-1324, Jan. 2013.

[7] "Ordinance No 1719 (Dec. 13, 2006), Cabinet of Ministers of Ukraine, "On the list of lines on which trains specialists in higher education for the qualification of Bachelor”', [Electronic source] Available:

http://zakon2.rada.gov.ua/laws/show/1719-2006-\%D0\%BF [Accessed Sept. 20, 2013]

[8] Letter No 1/9-736 (06.12.07), Minister of Education and Science of Ukraine, "On the list of directions (specialties) and their combination with additional specialties and specializations to prepare teachers for the educational qualification levels of Bachelor, Master," [Electronic source] Available: http://osvita.ua/legislation/Vishya_osvita/3200 [Accessed September 20, 2013] 